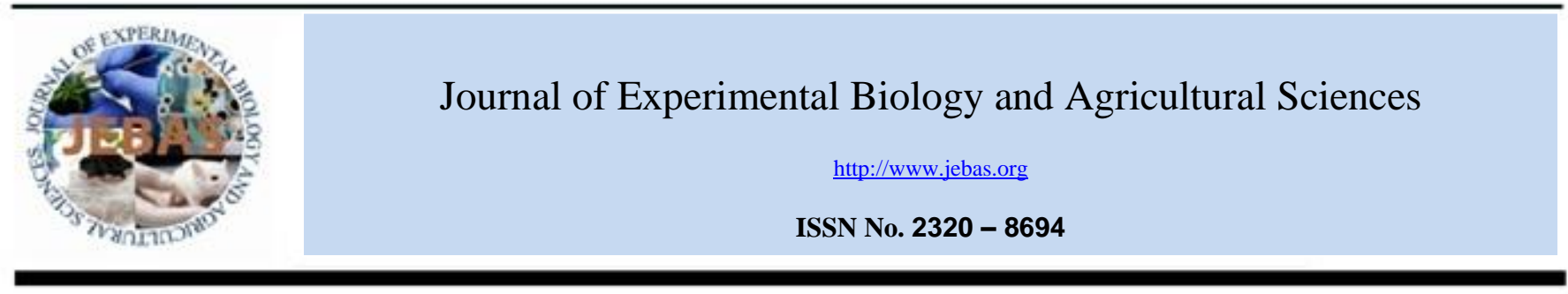

\title{
HARINGHATA BLACK CHICKEN SHOWS RESISTANCE TO PATHOGENIC E. coli BY HIGH IMMUNE-EFFECTOR ACTIVITIES
}

\author{
Sudip Nandi ${ }^{1}$, Siddhartha N. Joardar ${ }^{1, *}$, Indranil Samanta ${ }^{1}$, Bithi Roy ${ }^{1}$, Pradip K. Das ${ }^{2}$, Tapas K. Sar ${ }^{3}$ \\ and Sk Sahanawaz Alam ${ }^{1}$ \\ ${ }^{1}$ Department of Veterinary Microbiology, West Bengal University of Animal and Fishery Sciences, 37, Kshudiram Bose Sarani, Belgachia, Kolkata-700037,West \\ Bengal, India \\ ${ }^{2}$ Department of Veterinary Physiology (RKVY Laboratory), West Bengal University of Animal and Fishery Sciences, 37, Kshudiram Bose Sarani, Belgachia, \\ Kolkata-700037, West Bengal, India \\ ${ }^{3}$ Department of Veterinary Pharmacology and Toxicology, Faculty of Veterinary and Animal Sciences, West Bengal University of Animal and Fishery Sciences, \\ 37, Kshudiram Bose Sarani, Belgachia, Kolkata-700037, West Bengal, India
}

Received - January 25, 2016; Revision - February 21, 2016; Accepted - April 11, 2016

Available Online - April 25, 2016

DOI: http://dx.doi.org/10.18006/2016.4(2).149.155

KEYWORDS
Broiler
Disease resistance
E. coli
Haringhata black
Poultry
Rhode Island Red

\begin{abstract}
To substantiate the popular notion regarding disease-resistance potentiality of native breed of poultry against pathogens, immune responses in one native breed of India (Haringhata Black, HB), one of best adapted exotic breed of backyard system (Rhode Island Red, RIR) and commercial broiler birds against virulent $E$. coli were assessed upon experimental inoculation. Immunological parameters measured were superoxide production by heterophils, macrophage phagocytic activity, in vitro lymphoproliferation and antibody production against the antigens of $E$. coli. HB and RIR birds showed more cellular immune responses than that of broiler. Moreover, anti- E. coli antibody production was observed highest in HB than RIR and broiler as assessed by ELISA. Clinical manifestations in form of diarrhoea, roughned feather, rise of temperature as observed in broiler and RIR were not detected in HB birds. It is concluded that high immune responses shown by HB birds against virulent $E$. coli might be the driving factor of disease resistance as opposed to broiler and RIR birds where clinical symptoms were discernible.
\end{abstract}

* Corresponding author

E-mail: joardar69@gmail.com (Siddhartha N. Joardar)

Peer review under responsibility of Journal of Experimental Biology and Agricultural Sciences.

Production and Hosting by Horizon Publisher India [HPI] (http://www.horizonpublisherindia.in/).

All rights reserved.
All the article published by Journal of Experimental Biology and Agricultural Sciences is licensed under a Creative Commons Attribution-NonCommercial 4.0 International License Based on a work at www.jebas.org.

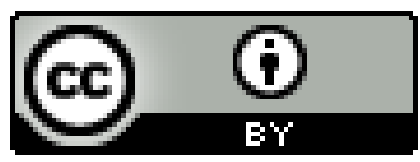




\section{Introduction}

The poultry and farm animals are considered as major reservoir of E. coli and Salmonella throughout the world without any clinical syndrome (Girlich et al., 2007; Carattoli, 2008; Watson et al., 2012; Samanta et al., 2014a). However, mode of disease resistance generated in native breeds of poultry against $E$. coli and its underlying immunological mechanism is not yet known (Samanta et al., 2014b). Therefore, it is quite expedient to study immune response patterns in native breeds of poultry to explore their scale of disease resistance against pathogenic $E$. coli (Samanta et al., 2015). Further, reports on antigenic characteristics of the target pathogen are scarce that might be useful while considering immunodiagnostic and/ or immunoprophylactic preparations against such pathogen (Roy et al., 2015). With this background the present study was conducted to assess cellular and humoral immune responses upon experimental inoculation of pathogenic E. coli in one native breed (Haringhata Black, HB), one of best adapted exotic breed of backyard system (Rhode Island Red, RIR), and commercial broiler birds in West Bengal, a major backyard and native breed rearing state in India.

\section{Materials and Methods}

\subsection{Experimental bird}

Rhode Island Red, Haringhata black and Broiler birds (3 months old) were used as experimental birds procured from the University Farm at Mohanpur, Nadia. Each variety of birds was divided into two groups viz. control group \& sensitized group, and each group contained 6 birds.

\subsection{Experimental design}

All the experimental birds were given normal feed (Amrit feed $^{\mathrm{TM}}$, India) containing maize, soyabean, ground nut cake, mineral mixture, vitamin up to the end of the experiment with ad libitum feed and water. The period of observation was started from the day of inoculation (0-day) with subsequent post inoculation periods, viz. $0,2^{\text {nd }}, 7^{\text {th }}, 14^{\text {th }}$ and $21^{\text {st }}$ days after inoculation. The Institute Ethics Committee of West Bengal University of Animal and Fishery Sciences, India approved this study.

\subsection{Sensitization of experimental bird}

After 7 days of acclimatization in experimental cages of the Department, all the birds of one group (sensitized) of each variety were inoculated (I/P) with virulent field isolate of ESBL producing E. coli [strain- SK-3, serogroup - O62, genotype- bla $\left.{ }_{T E M}(+\mathrm{ve}), b_{C T X-M}(-\mathrm{ve}), b_{S_{S H V}}(-\mathrm{ve})\right]$ bacteria $\left(10^{9} \mathrm{CFU} / \mathrm{ml}\right.$ dose). The field isolate (SK-3) was obtained from a local broiler (29 days old) which was suffering from diarrhoea, fever, roughened feather and was un-responding to higher group of cephalosporin antibiotics. Another group of birds were kept as control. The birds were maintained for observation up to 21 days. Neither the sensitized group nor the control group of birds in the present study for each category (HB, RIR, Broiler) received any kind of antibiotic during the study period.

\subsection{Antigen}

The somatic soluble antigen of the E. coli isolate (SK-3) was extracted by ultrasonication on ice at $150 \mathrm{~W}$ with repeating duty cycles and $0.5 \mathrm{sec}$ pulse pressure for two min with $30 \mathrm{sec}$ interval (five times) using an ultrasonicator (Hielscher Ultrasonics GmBH, Germany). The soluble sonicated extract was centrifuged at $10,000 \mathrm{~g}$ for $30 \mathrm{~min}$ at $4^{\circ} \mathrm{C}$ and the supernatant was collected as antigen as described earlier (Choi et al., 1989). The somatic soluble antigen was kept at $-20^{\circ} \mathrm{C}$ for further use.

\subsection{Protein Estimation}

Protein concentration of somatic soluble antigen was estimated using commercially available protein estimation kit (Merck Biosciences, India). The absorbance was measured at $660 \mathrm{~nm}$ by UV-VIS Spectrophotometer (TechComp, Taiwan).

\subsection{Leucocyte functional assay}

To measure non-specific immune response of poultry birds against pathogenic E. coli, oxidative radical production by heterophils was determined by the nitroblue tetrazolium (NBT) (SRL, India) reduction assay at different days post inoculation (DPI) period (Siwicki et al., 1998).

\subsection{Isolation of PBMC}

Heparinised blood was diluted with PBS at 1:1 ratio. For isolation of peripheral blood mononuclear cell (PBMC), diluted blood was layered onto HiSep ${ }^{\mathrm{R}}$ (Himedia, India) at the ratio of 2:3 (2 part of HiSep and 3 parts of cell suspension) and centrifuged for $30 \mathrm{~min}$ at $400 \mathrm{~g}$ (Chung \& Secombs, 1988). Using density gradient centrifugation, mononuclear cells from blood of poultry of the three varieties were isolated at different DPI as earlier. Enumeration of viable cells was done using Trypan blue dye exclusion method. In most of the cases $>90$ $\%$ of the cells were viable.

\subsection{Phagocytosis assay}

In vitro phagocytosis made by blood monocytes of the inoculated poultry birds was examined in different DPI as per Yoshida et al. (1993). The Phagocytic activity (PA) was determined as per Findlay \& Munday (2000) using the following formula-

Number of phagocytic cell




Stock solution of concanavalin A (Con A) was prepared at the concentration of $1 \mathrm{mg} / \mathrm{ml}$ of the growth medium (RPMI-1640), filtered through a sterile membrane filter $(0.22 \mu)$ and stored at $-20^{\circ} \mathrm{C}$ for future use. Stock solution of bacterial somatic soluble antigen was prepared at the concentration of $40 \mu \mathrm{g} / \mathrm{ml}$ with the growth medium (RPMI).

\subsection{Lymphoproliferation Assay (LPA)}

PBMC $\left(2 \times 10^{6}\right.$ cells $\left./ \mathrm{ml}\right)$ were suspended in RPMI-1640 and $100 \mu 1$ of cell suspension was dispended into wells of 96-well tissue culture plates. The final volume of each well was made up to $200 \mu \mathrm{l}$ with somatic antigen $(20 \mu \mathrm{g} / \mathrm{ml})$, Con A $(10$ $\mu \mathrm{g} / \mathrm{ml}$ ) (Sigma-Aldrich, USA) in positive control well and growth medium in negative control well. Finally, the plate was incubated at $37^{\circ} \mathrm{C}$ for $72 \mathrm{hr}$ under $5 \% \mathrm{CO}_{2}$ tension. The colorimetric 4,5- dimethylthiazol-2,5- diphenyltetrazolium bromide (MTT) (Sigma-Aldrich, USA) assay described by Daly et al. (1995) was used to determine the proliferation of blood lymphocytes in response of somatic antigen.

\subsection{Indirect Enzyme Linked Immunosobent Assay (i-ELISA)}

To detect anti- E. coli antibody in serum samples of RIR, HB and broiler birds (collected at 21 DPI), plate ELISA was performed based on the principle of indirect-ELISA as per Mockett et al. (1987) with some modifications.

\subsection{Statistical analysis}

The results of leukocyte functional assay, phagocytosis assay and lymphoproliferation assay were expressed as the mean \pm standard error of mean (SEM) and analysed using SPSS 21 (SPSS Inc. Chicago, USA).
Present study was aimed to detect changes in immune effector activities in three breeds of poultry viz. Haringhata Black, a native breed of India, Rhode Island Red, a backyard breed and broiler bird upon experimental inoculation of pathogenic $E$. coli isolate. The study revealed the comparative role of immune effector activities in three different poultry breeds by which they can resist pathogenic E. coli. The E. coli strain (SK-3) was selected for experimental inoculation because it was isolated from a local diseased broiler. Further, the isolate possessed bla ${ }_{\text {TEM }}$ gene which is one of the major ESBL genes produced by E. coli (bla ${ }_{T E M}$, bla ${ }_{S H V}$, bla ${ }_{\text {CTX-M }}$ ) and the bacteria of reservoir poultry chiefly harbours bla TEM (Olsen et al., 2014).

The broiler birds inoculated with pathogenic E. coli showed the clinical syndrome such as high fever, roughened feather and diarrhea within 7 days. In RIR birds intensity of diarrhea was less than the broiler birds. HB chickens didn't show any observable clinical sign and symptom. After 30 days, sensitized broiler birds died of the infection, although both of the sensitized HB and RIR birds survived. Probably the higher disease resistance potential in HB birds was responsible for the development of less severe clinical manifestation which was investigated in present study.

Super oxide anion produced by heterophils in E. coli inoculated Haringhata Black, Rhode Island Red and Broiler birds was significantly $(\mathrm{p}<0.05)$ higher during first $15^{\text {th }}$ DPI, however, lower in $21^{\text {st }}$ DPI in all the variety in comparison to the control birds (Table-1). Higher super oxide anion production by leucocytes of all the sensitized birds was corroborated with earlier works where significantly enhanced super oxide anion production was reported in treated chicken and turkey than control groups (Lowry et al., 2005; He et al., 2008; Paul et al., 2012).

Table 1 Assessment of super oxide production by blood leukocytes of $E$. coli inoculated (sensitized) and control birds at different days post inoculation by NBT reduction test.

\begin{tabular}{|lccccc|c|}
\hline Types of bird & Status of bird & $\mathbf{0 - d a y}$ & $\mathbf{2}^{\text {nd }}$ day & $\mathbf{7}^{\text {th }}$ day & $\mathbf{1 4}^{\text {th }}$ day & $\mathbf{2 1}^{\text {st }}$ day \\
\hline HB & Sensitized & $0.426 \pm 0.009^{\mathrm{b}}$ & $1.892 \pm 0.005^{\mathrm{a}}$ & $1.745 \pm 0.007^{\mathrm{a}}$ & $1.085 \pm 0.183^{\mathrm{a}}$ & $0.490 \pm 0.003^{\mathrm{c}}$ \\
\cline { 2 - 7 } & Control & $0.413 \pm 0.003^{\mathrm{b}}$ & $0.399 \pm 0.002^{\mathrm{b}}$ & $0.406 \pm 0.001^{\mathrm{b}}$ & $0.418 \pm 0.009^{\mathrm{b}}$ & $0.421 \pm 0.005^{\mathrm{b}}$ \\
\hline \multirow{2}{*}{ RIR } & Sensitized & $0.321 \pm 0.004^{\mathrm{b}}$ & $1.576 \pm 0.003^{\mathrm{a}}$ & $1.559 \pm 0.005^{\mathrm{a}}$ & $1.168 \pm 0.040^{\mathrm{a}}$ & $0.315 \pm 0.008^{\mathrm{c}}$ \\
\cline { 2 - 7 } & Control & $0.318 \pm 0.004^{\mathrm{b}}$ & $0.347 \pm 0.006^{\mathrm{b}}$ & $0.325 \pm 0.007^{\mathrm{b}}$ & $0.321 \pm 0.008^{\mathrm{b}}$ & $0.319 \pm 0.011^{\mathrm{b}}$ \\
\hline \multirow{2}{*}{ Broiler } & Sensitized & $0.495 \pm 0.022^{\mathrm{b}}$ & $1.128 \pm 0.001^{\mathrm{a}}$ & $1.221 \pm 0.004^{\mathrm{a}}$ & $1.022 \pm 0.029^{\mathrm{a}}$ & $0.530 \pm 0.005^{\mathrm{c}}$ \\
\cline { 2 - 7 } & Control & $0.487 \pm 0.010^{\mathrm{b}}$ & $0.469 \pm 0.004^{\mathrm{b}}$ & $0.413 \pm 0.003^{\mathrm{b}}$ & $0.492 \pm 0.010$ & $0.471 \pm 0.010^{\mathrm{b}}$ \\
\hline
\end{tabular}

HB-Haringata Black, RIR-Rhode Island Red

Results shown are mean of six observations \pm SEM

The mean bearing different superscript in the same row and column differs significantly $(\mathrm{p}<0.05)$ 
Table 2 Phagocytic activity of PBMC of E. coli inoculated (sensitized) and control birds at different days post inoculation

\begin{tabular}{|lllllll|}
\hline Types of bird & Status of bird & $\mathbf{0 - d a y}$ & $\mathbf{2}^{\text {nd }}$ day & $\mathbf{7}^{\text {th }}$ day & $\mathbf{1 4}^{\text {th }}$ day & $\mathbf{2 1}^{\text {st }}$ day \\
\hline \multirow{2}{*}{ HB } & Sensitized & $15 \pm 0.032^{\mathrm{c}}$ & $22 \pm 0.023^{\mathrm{b}}$ & $21 \pm 0.023^{\mathrm{b}}$ & $19 \pm 0.024^{\mathrm{b}}$ & $27 \pm 0.033^{\mathrm{a}}$ \\
\cline { 2 - 7 } & Control & $15 \pm 0.023^{\mathrm{c}}$ & $16 \pm 0.021^{\mathrm{c}}$ & $14 \pm 0.026^{\mathrm{c}}$ & $14 \pm 0.031^{\mathrm{c}}$ & $16 \pm 0.028^{\mathrm{c}}$ \\
\hline \multirow{2}{*}{ RIR } & Sensitized & $18 \pm 0.024^{\mathrm{c}}$ & $24 \pm 0.022^{\mathrm{b}}$ & $25 \pm 0.021^{\mathrm{b}}$ & $24 \pm 0.025^{\mathrm{b}}$ & $30 \pm 0.031^{\mathrm{a}}$ \\
\cline { 2 - 7 } & Control & $17 \pm 0.026^{\mathrm{c}}$ & $15 \pm 0.030^{\mathrm{c}}$ & $16 \pm 0.032^{\mathrm{c}}$ & $15 \pm 0.032^{\mathrm{c}}$ & $16 \pm 0.027^{\mathrm{c}}$ \\
\hline \multirow{2}{*}{ Broiler } & Sensitized & $13 \pm 0.023^{\mathrm{b}}$ & $19 \pm 0.022^{\mathrm{a}}$ & $18 \pm 0.028^{\mathrm{a}}$ & $17 \pm 0.028^{\mathrm{a}}$ & $13 \pm 0.023^{\mathrm{b}}$ \\
\cline { 2 - 7 } & Control & $12 \pm 0.031^{\mathrm{b}}$ & $11 \pm 0.033^{\mathrm{b}}$ & $12 \pm 0.032^{\mathrm{b}}$ & $11 \pm 0.034^{\mathrm{b}}$ & $14 \pm 0.024^{\mathrm{b}}$ \\
\hline
\end{tabular}

HB-Haringata Black, RIR-Rhode Island Red

Results shown are mean of six observations \pm SEM

The mean bearing different superscript in the same row and column differ significantly $(\mathrm{p}<0.05)$

The phagocytic activity (PA) of PBMC of E. coli inoculated and control HB, RIR and Broiler birds are presented in Table 2. The sensitized broiler birds showed little higher PA values $(19 \pm 0.022)$ at 2 nd DPI which was decreased $(13 \pm 0.023)$ in $21^{\text {st }}$ DPI. Whereas, sensitized HB and RIR birds showed higher PI values at $2^{\text {nd }}(22 \pm 0.023$ and $24 \pm 0.022), 7^{\text {th }}(21 \pm 0.023$ and $25 \pm 0.021), 14^{\text {th }}(19 \pm 0.024$ and $24 \pm 0.025)$ and $21^{\text {st }}(27 \pm 0.033$ and $30 \pm 0.031)$ DPI than the control birds. In short, higher phagocytic activity of HB and RIR PBMC was observed than the broiler birds and it was maintained up to $21^{\text {st }}$ DPI. Similar significant higher phagocytic potential of macrophages in treated chicken was reported by previous workers against $E$. coli (Qureshi, 1998).

Lymphocyte proliferation upon conA and antigen stimulation of blood leucocytes of experimental birds are expressed as stimulation index (Table -3). Sensitized HB birds showed similar SI values on the first day $(0.413 \& 0.359)$ with that of control birds $(0.401 \& 0.343)$ but it significantly $(\mathrm{p}<0.05)$ differed on $14^{\text {th }}$ and $21^{\text {st }}$ DPI. An increase in stimulation index was noticed on $14^{\text {th }}$ day $(0.478 \& 0.462)$ and $21^{\text {st }}$ day $(0.522 \&$ $0.517)$ post inoculation. Sensitized RIR birds showed similar SI values on the first day $(0.413 \& 0.359)$ with that of control birds $(0.439 \& 0.285)$ but it significantly $(\mathrm{p}<0.05)$ differed on $14^{\text {th }}$ and $21^{\text {st }}$ DPI. An increase in stimulation index was noticed on $14^{\text {th }}(0.478 \& 0.327)$ and $21^{\text {st }}$ DPI $(0.534 \& 0.473)$. Sensitized broilers showed similar SI values $(0.237 \& 0.192)$ with that of control $(0.194 \& 0.183)$ on 0 -day but it significantly $(\mathrm{p}<0.05)$ differed on $14^{\text {th }}$ DPI. An increase in stimulation index was noticed on $14^{\text {th }}$ DPI $(0.363 \& 0.301)$ but that decreased at $21^{\text {st }}$ DPI $(0.218 \& 0.183)$. Similar significant enhanced proliferation of blood leucocytes was detected in treated broiler chicken (Lee et al., 2007). Moreover, in vitro lymphocyte proliferation of peripheral blood leucocytes (PBL) was reported in treated broiler chicken that gave 100\% protection in IBD virus challenge (Tayade et al., 2006). In the present study, high specific cellular stimulation (in form of lymphocyte proliferation) was noted up to $21^{\text {st }}$ DPI in HB birds than RIR and broiler that might be related to its enhanced immune potential.

The seroreactivity expressed as O.D. values were $0.82 \pm 0.021$ in sensitized HB birds, $0.74 \pm 0.032$ in sensitized RIR and $0.47 \pm 0.017$ in sensitized broiler birds (Figure 1) with experimental sera at 1:400 dilution, respectively. Whereas, the O.D. values were detected from $0.583 \pm 0.032 ; 0.534 \pm 0.022$ and $0.433 \pm 0.025$, respectively for the same range of dilution with the sera of control birds. The humoral immune -effector activity measured by indirect ELISA to detect anti- E. coli antibody in serum samples of RIR, HB, and broiler birds showed enhanced seroreactivity in all the sensitized than the control birds. Similar enhanced seroreactivity in E. coli sensitized birds were observed by Mukherjee (2006) and Mitra (2007) using i-ELISA. In the present study, highest seroreactivity was noted in HB birds compared to RIR and brolier birds indicating more immune-potential of the breed.

Table 3 Lymphoproliferation assay of PBMC of E. coli inoculated (sensitized) and control birds at different days post inoculation

\begin{tabular}{|c|c|c|c|c|c|c|c|c|c|}
\hline \multirow{2}{*}{$\begin{array}{c}\text { Types of } \\
\text { bird }\end{array}$} & \multirow{2}{*}{$\begin{array}{c}\text { Status of } \\
\text { bird }\end{array}$} & \multicolumn{2}{|c|}{ 0-day } & $7^{\text {th }}$ day & \multirow[b]{2}{*}{ Antigen } & \multicolumn{2}{|c|}{$14^{\text {th }}$ day } & \multicolumn{2}{|c|}{$21^{\text {st }}$ day } \\
\hline & & ConA & Antigen & ConA & & ConA & Antigen & ConA & Antigen \\
\hline \multirow[t]{2}{*}{$\mathrm{HB}$} & Sensitized & $0.413 \pm 0.009^{\mathrm{b}}$ & $0.359 \pm 0.016^{\mathrm{c}}$ & $0.471 \pm 0.011^{\mathrm{b}}$ & $0.402 \pm 0.021^{b}$ & $0.478 \pm 0.013^{b}$ & $0.462 \pm 0.021^{b}$ & $0.522 \pm 0.006^{\mathrm{a}}$ & $0.517 \pm 0.019^{\mathrm{a}}$ \\
\hline & Control & $0.401 \pm 0.006^{\mathrm{b}}$ & $0.343 \pm 0.008^{c}$ & $0.400 \pm 0.009^{\mathrm{c}}$ & $0.384 \pm 0.006^{\mathrm{c}}$ & $0.434 \pm 0.021^{b}$ & $0.384 \pm 0.006^{\mathrm{c}}$ & $0.422 \pm 0.008^{\mathrm{b}}$ & $0.351 \pm 0.010^{\mathrm{c}}$ \\
\hline \multirow[t]{2}{*}{ RIR } & Sensitized & $0.439 \pm 0.006^{\mathrm{b}}$ & $0.285 \pm 0.009^{\mathrm{c}}$ & $0.421 \pm 0.014^{\mathrm{b}}$ & $0.327 \pm 0.013^{\mathrm{c}}$ & $0.478 \pm 0.011^{b}$ & $0.327 \pm 0.013^{\mathrm{c}}$ & $0.534 \pm 0.010^{\mathrm{a}}$ & $0.473 \pm 0.003^{\mathrm{a}}$ \\
\hline & Control & $0.421 \pm 0.010^{\mathrm{b}}$ & $0.273 \pm 0.003^{\mathrm{c}}$ & $0.422 \pm 0.010^{\mathrm{b}}$ & $0.265 \pm 0.003^{\mathrm{c}}$ & $0.425 \pm 0.013^{b}$ & $0.265 \pm 0.003^{\mathrm{c}}$ & $0.429 \pm 0.011^{\mathrm{b}}$ & $0.281 \pm 0.006^{\mathrm{c}}$ \\
\hline \multirow[t]{2}{*}{ Broiler } & Sensitized & $0.237 \pm 0.010^{c}$ & $0.192 \pm 0.004^{\mathrm{d}}$ & $0.269 \pm 0.002^{\mathrm{c}}$ & $0.301 \pm 0.006^{\mathrm{c}}$ & $0.363 \pm 0.010^{\mathrm{c}}$ & $0.301 \pm 0.006^{\mathrm{c}}$ & $0.218 \pm 0.010^{\mathrm{c}}$ & $0.183 \pm 0.003^{\mathrm{d}}$ \\
\hline & Control & $0.194 \pm 0.007^{\mathrm{d}}$ & $0.183 \pm 0.005^{\mathrm{d}}$ & $0.231 \pm 0.005^{\mathrm{c}}$ & $0.175 \pm 0.006^{\mathrm{d}}$ & $0.241 \pm 0.005^{\mathrm{c}}$ & $0.178 \pm 0.006^{\mathrm{d}}$ & $0.243 \pm 0.007^{\mathrm{c}}$ & $0.201 \pm 0.005^{\mathrm{d}}$ \\
\hline
\end{tabular}

HB-Haringata Black, RIR-Rhode Island Red

Results shown are mean of six observations \pm SEM

The mean bearing different superscript in the same row and column differ significantly $(\mathrm{p}<0.05)$ 


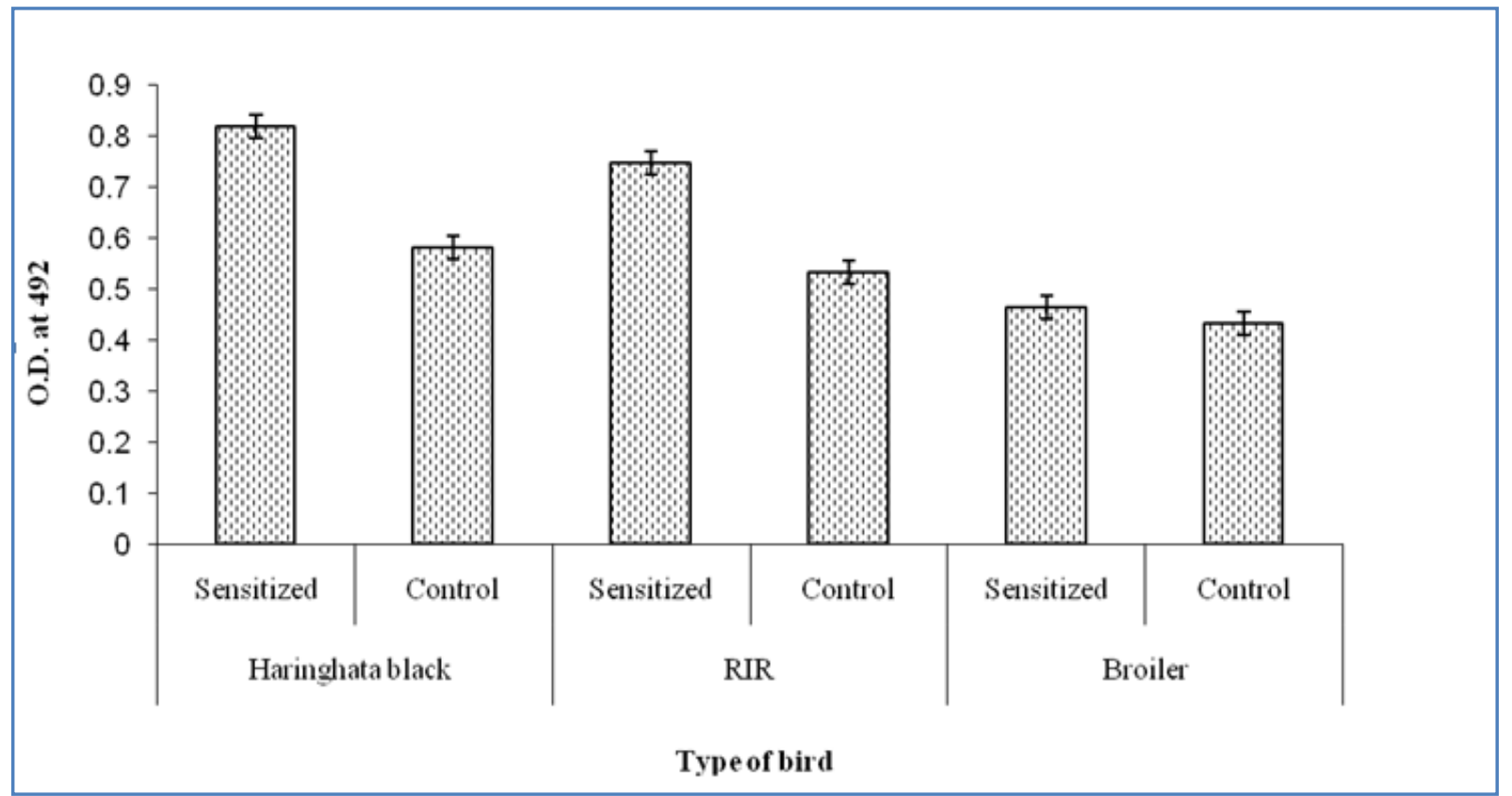

Figure 1 Assessment of anti-E. coli $\mathrm{O} 62$ antibodies in poultry birds by enzyme linked immunosorbent assay (Serum dilution-1:400; Results shown are mean of six observations \pm SEM).

Thus, the present study showed enhanced cellular and humoral immune effector activities in native and backyard poultry breed than the test broiler birds against pathogenic E. coli. Similarly, Munir et al. (2010) detected a virulent Newcastle disease virus in backyard birds without any clinical syndrome probably due to enhanced immune effector activities which was unexplored in the conducted study. Further, in a comparative study between a native chicken (Erlang mountainous chicken) and commercial broiler in China, native chicken breed showed higher resistance against Marek's disease virus than the broiler due to difference in expression pattern of transcription factor $(I R F-3)$ and interferon $(I F N-\beta)$ genes associated with genetic background (Feng et al., 2013). Emam et al. (2014) also detected the possible role of genetic background in different immune response (in vitro blood mononuclear cell proliferation) between native chicken and broiler birds against sheep red blood cell and Brucella antigen.

\section{Conclusions}

The present study detected dynamic changes in cellular and humoral immune responses in all the poultry breeds/strain used upon exposure to pathogenic E. coli during study period. However, HB birds showed higher cellular and humoral immune responses against pathogenic E. coli than the other test birds that corroborates their resistance from experimental infection. Continuation of the study may affirm the disease resistance potential of this native breed at genetic level.

\section{Acknowledgements}

This work was supported by the grant (BT/164/NE/TBP/2011) of Twinning Programm for NE, sponsored by The Department of Biotechnology, Ministry of Science and Technology, Government of India, New Delhi. Authors are thankful to the Vice Chancellor, West Bengal University of Animal and Fishery Sciences, Kolkata for providing necessary infrastructure ficilities. No financial interests or benefits are arising from the direct applications of the present study.

\section{Conflict of Interests}

Authors would hereby like to declare that there is no conflict of interests that could possibly arise.

\section{References}

Carattoli A (2008) Animal reservoirs for extended-spectrum beta-lactamase producers. Clinical Microbiology and Infection 14:117-123. DOI: 10.1111/j.1469-0691.2007.01851.x

Choi KH, Maheswaran SK, Felice LJ (1989) Characterization of outer membrane protein enriched extracts from Pasteurella multocida isolated from turkeys. American Journal of Veterinary Research 50: 676-683. 
Chung S, Secombes C J (1988) Analysis of events occurring within teleost macrophages during the respiratory burst. Comparative Physiology and Biochemistry 89: 539-544.

Daly JG, Olivier G, Moore AR (1995) A calorimetric assay for the quantification of brook trout (Salvelinus fontinalis) lymphocyte mitogenesis. Fish and Shellfish Immunology 5: 266-273.

Emam M, Mehrabani-Yeganeh H, Barjesteh N, Nikbakht G, Thompson-Crispi K, Charkhkar S, Mallard B (2014) The influence of genetic background versus commercial breeding programs on chicken immunocompetence. Poultry Science 93: 77-84. doi: 10.3382/ps.2013-03475.

Feng ZQ, Lian T, Huang Y, Zhu Q, Liu YP (2013) Expression pattern of genes of RLR-mediated antiviral pathway in different-breed chicken response to Marek's Disease virus infection. BioMed Research International. doi: $10.1155 / 2013 / 419256$

Findlay VL, Munday BL (2000) The immunomodulatory effects of levamisole on the salmon, Salmo salar L. Journal of Fish Disease 23: 369-378. DOI: 10.1046/j.13652761.2000.00231.x

Girlich D, Poirel L, Carattoli A, Kempf I, Lartigue M, Bertini A, Nordmann P (2007) Extended-Spectrum $\beta$-Lactamase CTXM-1 in Escherichia coli isolates from healthy poultry in France. Applied and Environmental Microbiology 73: 46814685. doi: 10.1128/AEM.02491-06.

He H, Genovese KJ, Swaggerty CL, Nisbet DJ, Kogut MH (2008) Differential induction of nitric oxide, degranulation, and oxidative burst activities in response to microbial agonist stimulations in monocytes and heterophils from young commercial turkeys. Veterinary Immunology and Immunopathology 123: 177-185. doi: 10.1016/j.vetimm.2008.01.033.

Lee SH, Lillehoj HS, Chun HK, Tuo W, Park HJ, Cho SM, Lee YM, Lillehoj EP (2007) In vitro treatment of chicken peripheral blood lymphocytes, macrophages, and tumor cells with extracts of Korean medicinal plants. Nutrition Research 27: 362-366. doi:10.1016/j.nutres.2007.04.001.

Lowry VK, Farnell MB, Ferro PJ, Swaggerty CL, Bahl A, Kogut MH (2005) Purified beta-glucan as an abiotic feed additive up-regulates the innate immune response in immature chickens against Salmonella enterica serovar Enteritidis. International Journal of Food Microbiology 98: 309-18. doi:10.1016/j.ijfoodmicro.2004.06.008.

Mitra D (2007) Immunobiochemical characterization of Escherichia coli serotypes isolated from poultry. M. V. Sc. Thesis submitted to West Bengal University of Animal and Fishery Sciences, Kolkata.
Mockett AP, Cook JK, Huggins MB (1987) Maternallyderived antibody to infectious bronchitis virus: its detection in chick trachea and serum and its role in protection. Avian Pathology 16: 407-416. DOI:10.1080/03079458708436391.

Mukherjee R (2006) Isolation and immunobiochemical characterization of sonicated extract, secretory and membrane proteins of $E$. coli isolates of dog. M. V. Sc. Thesis submitted to West Bengal University of Animal and Fishery Sciences, Kolkata.

Munir M, Abbas M, Khan MT, Zohari S, Berg M (2012) Genomic and biological characterization of a velogenic Newcastle disease virus isolated from a healthy backyard poultry flock in 2010. Virology Journal 16: 9-46. DOI: 10.1186/1743-422X-9-46.

Olsen RH, Bisgaard M, Löhren U, Robineau B, Christensen H (2014) Extended-spectrum $\beta$-lactamase-producing Escherichia coli isolated from poultry: a review of current problems, illustrated with some laboratory findings. Avian Pathology 43:199-208. doi: 10.1080/03079457.2014.907866.

Paul I, Isore DP, Joardar SN, Samanta I, Biswas U, Maiti TK, Gaguly S, Mukhopadhyay SK (2012) Orally administered $\beta$ glucan of edible mushroom (Pleuratus florida) origin up regulates innate immune response in broiler. Indian Journal of Animal Sciences 82: 745-748.

Qureshi MA (1998) Role of macrophages in avian health and disease. Poultry Science 77: 978-982.

Roy B, Joardar SN, Samanta I, Das PK, Alam SS, Nandi S (2015) Detection of T- and B- cell antigens of fowl pox virus isolated from backyard chickens in India. Avian Diseases 59: 249-254. doi: 10.1637/11031-020415-Reg.

Samanta I, Joardar SN, Das PK, Sar T, Bandyaopadhyay S, Dutta TK, Sarkar U (2014a) Prevalence and antibiotics resistance profiles of Salmonella serotypes isolated from backyard poultry flocks in West Bengal, India. Journal of Applied Poultry Research 23: 1-10. doi: 10.3382/japr.201300929.

Samanta I, Joardar SN, Das PK, Das P, Sar, TK, Dutta TK, Bandyopadhyay S, Batabyal S, Isore D (2014b) Virulence repertoire, characterization and antibiotic resistance pattern analysis of Escherichia coli isolated from backyard layers and their environment in India. Avian Diseases 58: 39-45.

Samanta I, Joardar SN, Das PK, Sar TK (2015) Comparative possession of Shiga toxin, intimin, enterohaemolysin and major extended spectrum beta lactamase (ESBL) genes in $E$. coli isolated from backyard and farmed poultry. Iranian Journal of Veterinary Research 16: 90-93.

Siwicki AK, Klein P, Morand M, Kiczka W, Studnicka M (1998) Immunostimulatory effects of dimerized lysozyme 
(KLP-602) on the nonspecific defense mechanisms and protection against furunculosis in salmonids. Veterinary Immunology and Immunopathology 61: 369-378. doi:10.1016/S0165-2427(97)00140-2.

Tayade C, Koti M, Mishra SC (2006) L-Arginine stimulates intestinal intraepithelial lymphocyte functions and immune response in chickens orally immunized with live intermediate plus strain of infectious bursal disease. Vaccine 24: 5473-5480. doi:10.1016/j.vaccine.2006.03.086.
Watson E, Jeckel S, Snow L, Stubbs R, Teale C, Wearing H, Horton R, Toszeghy M, Tearne O, Ellis-Iversen J, Coldham N (2012) Epidemiology of extended spectrum beta-lactamase $E$. coli (CTX-M-15) on a commercial dairy farm. Veterinary Microbiology 154: 339-346. 10.1016/j.vetmic.2011.07.020.

Yoshida T, Sakai M, Kitao T, Khill SM, Araki S, Saito R, Ineno T, Inglia V (1993) Immunomodulatory effects of the fermented products of chicken egg. EF203, on rainbow trout, Onchorhynchus mykiss. Aquaculture 109: 207-214. doi:10.1016/0044-8486(93)90163-S. 